\title{
GENDER AND REGIONAL INEQUALITY IN HUMAN DEVELOPMENT: THE CASE OF SPAIN ${ }^{1}$
}

\author{
Javier Martínez Peinado \\ Gemma Cairó Céspedes
}

\begin{abstract}
In this paper, we present estimates of the Human Development Index and the Gender-Related Development Index in the Autonomous Communities of Spain. Our case study of Spain, a developed country with clear gender and regional differences, demonstrates the importance of adjusting human development indices in accordance with gender discrimination and regional inequalities. We also show the significance of the income component in assessing the development level of women in countries like Spain, where lack of employment or low remuneration are the chief characteristics of women's inequality. Our analysis makes clear that the gender-related human development index has limited applicability in developed countries; it also illustrates the need for alternative variables or models to assess inequality in those countries.
\end{abstract}

Keywords: Gender, Human Development, HDI, GDI, Spain, Autonomous Communities JEL codes: $\mathrm{C} 8, \mathrm{O} 1, \mathrm{R} 1$

Running Header: Gender and Human Development 


\section{Introduction}

Despite ongoing debates over issues of gender and development, namely, the relationship between the productive and reproductive spheres, and the connection between economic growth and basic needs, participants in the debates concur on the usefulness of a Gender-Related Development Index (GDI). This index is an extension of the Human Development Index (HDI), which measures achievement in enlarging people's choices, capabilities, and opportunities. Intended as an alternative to using per-capita Gross National Product (GNP) to assess development, the HDI surveys such areas as health, knowledge, and access to resources and treats income as a variable with decreasing returns. As a human development paradigm, the HDI states that social development can no longer be defined in the purely monetary terms of capitalist development. Valuable as the HDI is, however, it is incomplete. The growing use of gender and development approaches have drawn attention to the fact that development and its problems cannot be fully understood without also considering gender; this is where the GDI has proved useful.

The GDI functions as a human development index (HDI) that takes the status of women into account. Composed of the harmonic mean of male and female values for life expectancy, educational attainment (adult literacy and gross ratio of men to women in school enrollment), and share of income (labor and income), it indicates the general level of human development, particularly for women

However, the GDI is better suited to measure gender inequality in developing countries than in developed ones. Its parameters introduce a bias into the assessment of human development itself: while men and women in developed countries have more equal access to health care and education than their counterparts in less-developed countries, the income variable 
has a stronger influence on the disparities between men and women. Yet although the GDI is not the best direct indicator of gender inequality in developed countries, it remains a useful tool for assessing the general level of human development, since in these societies the basic needs defined by the HDI components are met to a great extent.

When societies achieve high standards of material welfare - leaving aside value judgments on welfare, happiness, and desirable ways of life - the human development level must be calculated with gender and regional inequalities in mind. Such inequalities matter because, in a developed country, "exclusions," "human development privations," and "human suffering profiles" are meaningful only if based on some measure of discrimination and differences in capabilities and opportunities, rather than on actual material deprivation. In wealthy countries, high general levels of human development can be said to occur only when they do not exclude any essential sphere of society, including women.

A study of levels of development in Spain yields interesting results for at least two reasons. First, the country's political system allows a transfer of educational and health administration from the central government to Spain's seventeen Autonomous Communities (administrative units that correspond to Spain's historic and geographic regions). Traditionally called "different Spains" (North/South, interior/coastal, humid/dry, modern/traditional, rich/poor, etc.), the regions have varying degrees of self-government and have received different powers regarding social policies. Second, the level of women's integration into the paid productive sphere in Spain is one of the lowest in Europe and in the rest of the developed world. Furthermore, unemployment among Spanish women is well above that of men. Spain is thus an example of a developed country with clear gender and regional differences. In light of these facts, can we still consider the GDI of the Autonomous Communities to be meaningful? 
To answer this question, we examine GDI estimates for Spain within the context of applying the gender approach to human development in developed countries. First we show the connection between gender approaches and underdevelopment; next, we link these approaches to the human development paradigm, particularly to its application in developed countries. We then consider the case of Spain and estimate the GDI for the different Autonomous Communities. Finally, we test two alternatives to the GDI and offer conclusions on how to assess levels of discrimination against women in developed countries.

\section{Women and development: from invisibility to an alternative paradigm}

Until the 1980s, mainstream economists did not consider gender a key factor in measuring development, and paradigms of economic development rarely included a gender approach. Neither theories of economic growth and modernization, nor alternative theories of external dependence and neo-imperialism, paid much attention to the role of women. Only the neoMalthusian interpretations of demographic growth dealt with the reproductive sphere, and only as an obstacle to development itself. But even the neo-Malthusians relegated women to minor roles. ${ }^{2}$ Starting in the 1970s a new approach emerged, called WID (Women in Development). The aim of this approach was to integrate women into the development process (productive sphere).

Esther Boserup (1993; originally published in 1970) played an essential and pioneering role in developing this approach. Her analysis of the agricultural systems of the developing world revealed two issues: the discrimination against women at all levels of the development process (division of labor, access to property, education, etc.); and the sociocultural roots of this discrimination. She focused on the need to integrate women into the development process. The activists, academicians, and policy makers who support the WID approach still endorse Boserup's "integrative" approach, which strives to put an end to women's "invisibility" in mainstream 
development (Irene Tinker 1990). Another valuable aspect of Boserup's approach is it provides a rationale for fostering women's productive role.

However, feminists have criticized Boserup for not questioning how the development process occurs and for not mentioning the relations of domination within the reproductive sphere (Lourdes Benería and Gita Sen 1997). Boserup's later efforts to apply the integrative approach have inspired similar criticisms. In particular, many feminists believe her conceptual framework is too dependent on neoclassical categories and modernization theory, which identify women's problems with their lack of access to the benefits of modernization. This assumption ignores the dynamics of capitalist accumulation, which have important implications for technological change, women's work, and the effects of working on women of different classes. These critics also point out that Boserup neglects women's roles in the reproduction of the labor force -- a role that tends to weaken women's position in the labor market and leads to asymmetrical gender relationships. Thus, Boserup does not fully capture the problem of subordination. ${ }^{3}$

Since the 1980s, the socioeconomic situation of the developing world has been getting worse. Acting as agents of the "Washington Consensus" -- which held that focusing on free markets would spur economic development -- international agencies imposed Structural Adjustment Programs (SAPs). These programs, which promoted free-market mechanisms as a means of achieving growth and development, reduced social services such as health, education, and employment programs, thereby increasing poverty and making exclusion widespread among people in the weakest social strata. SAPs replaced "development strategies"; the former development-oriented paradigm was considered obsolete.

As one result of SAPs, women suddenly achieved a "new" prominence. Neoliberal theorists recognized their crucial role in the reproductive sphere and the importance of that sphere for efforts to reduce poverty. The official view, especially that of the World Bank, tends to focus 
on women's efficiency and productivity as housewives and mothers (in other words, as "domestic entrepreneurs"). Many women economists have responded by pointing out the discrimination faced by women, both in the reproductive and productive spheres, while also linking it to strong criticisms of SAPs (Lourdes Benería 1992; Diane Elson 1995; Maria Floro 1995; Isabella Bakker 1999; Ruth Pearson 1999; Diane Elson and Nilufer Cagatay 2000). Aiming to analyze the relationships among gender, poverty, and inequality, these scholars have questioned the neoliberal adjustment paradigm, refuting the claim that the market is the only mechanism that will allocate resources efficiently and enable growth and development. Their work has ties to the growing criticism, in intellectual sectors, of the identification of growth with development, of progress with markets, and of expenditures with welfare. This criticism provides alternative ways to define development (such as meeting basic needs, equality, and participation), going beyond the dictates of per-capita gross national product and its growth rate. Hence, critical analyses from the point of view of gender and from the perspective of development are linked.

After the UN Women's Conference of 1985, held in Nairobi, the GAD (Gender and Development) approach gained momentum. This approach emphasizes the notion of women's empowerment; it also highlights the interactive relationship between subordination and exploitative economic structures, both in productive and reproductive spheres. According to proponents of GAD, this interaction directly relates to the nature of capitalist modernization in the third world. Diane Elson, Naila Kabeer, Isabella Bakker, Lourdes Benería, and Ruth Pearson, among many other scholars in this area, have stressed not simply the "integration" of women into the economy, development, or adjustment, but the way in which this integration takes place, a view that has led them to analyze the reproductive sphere as well.

The GAD approach criticizes macroeconomic theory for taking the "reproductive economy" for granted and assuming it will easily adapt to the changes caused by adjustment 
measures and any other policies the state implements. By adhering to this belief, macroeconomists overlook the interrelationship between production and reproduction. The consequence is a hindering of women's development, since policies that ignore reproduction give women heavier workloads than men's and secondary labor market status; they also heighten inequality and subordination (Bakker 1999).

Nevertheless, it is precisely the reproductive sphere - which includes, among other tasks, women's community services and care-giving responsibilities - that plays a major role in human development, defined as the fostering of people's capabilities and opportunities (such care work is disproportionately the charge of women). This is why heterodox feminists, who have moved beyond stressing the lack of gender-aware approaches within adjustment, point to the limitations of adjustment measures and pro-capitalist development models in assuring higher levels of human development. They argue that the structural changes these models incur -- including adjustments in asset property, shifts in political power, a rise in social inequality, and the privatization of social reproduction costs -- actually lead to an overall drop in human welfare.

Feminist analysis highlights the fact that reproduction and maintenance of human resources differs from any other kind of production (Zabala 1999: 352); it questions the ability of the market, not only to value reproductive work, but also to guarantee the achievement of human development objectives. Thus, in both developed and developing countries, the prominence of the reproductive role is crucial to understanding the reality of women's role in the productive sphere. Only by transforming existing gender and power relations will women achieve a higher level of social welfare.

The GAD approach has two aspects. It is both an analytical framework for determining women's status and a political proposal to overcome gender inequalities by simultaneously analyzing gender relations and providing a holistic perspective on the relationship between 
production and reproduction. According to Kate Young (1997a, 1997b), the GAD has two aims (political and theoretical), because of the need to achieve higher levels of awareness and organization among women. Once women achieve such awareness, they will understand the nature of poverty and inequality-creating structures and how inequality between men and women prevents their achieving greater development.

Ultimately, the "empowerment of women"-- women's right to control their own lives and to decide on their personal agendas -- paves the way for transforming the existing structures of subordination. For example, the empowerment model launched in the eighties by Development Alternatives with Women for a New Era (DAWN) -- a network of women scholars and activists from the South -- builds on the concept of human development, or the fostering of individual capabilities and opportunities for people to achieve better lives.

This new paradigm, which was first proposed by the United Nations Development Program (UNDP) in its 1990 Human Development Report, transcends the debate between defenders of economic growth and those in favor of meeting basic needs; it crowns the critical analysis of economic development. Its immediate objectives -- which focus primarily on the problems of underdevelopment -- emphasize not only the importance of human capital but also that of distribution and equity, and of a "people centered" approach. In seeking a synthesis between a gender approach and the human development approach, the UNDP created the GDI and, later, the Gender Empowerment Measure, or GEM.

Both the GDI and its predecessor, the HDI, were constructed with gender awareness. As we have previously argued, however, they do not sufficiently account for gender inequality in developed countries. This study is an attempt to construct indices for the Autonomous Communities of Spain that account for gender discrimination and are alternatives to the GDI. 


\section{Human Development and Gender}

The UNDP's synthesis of the two approaches to underdevelopment -- gender and human development -- resulted from an understanding of the discrimination suffered by women in terms of capabilities and opportunities in human development areas (such as a long and healthy life, education, and a decent standard of living). Economists can measure this discrimination empirically by evaluating the different ratings for men and women in life expectancy, educational attainment, and income indices.

From the beginning, the authors of the Human Development Reports tried to include regional and gender inequalities in the HDI, since national averages overlooked those aspects. As for gender, the first reports dealt with inequality by comparing women's indices with men's, but the 1995 Human Development Report included gender inequality in the HDI itself in order to avoid underestimating the "general achievement" of both men and women. The result was the Gender-Related Development Index (and, later, the GEM). The GDI is also a step toward increased awareness of inequality, since it introduces a certain "aversion" to inequality. It does so by especially taking into account the lesser achievements of women, caused by discrimination. Users employ harmonic means, which focus on small values, to calculate the index, instead of relying on arithmetic means, which are biased by big values. The GDI is, in fact, an HDI discounted, or adjusted downward, for gender inequality: the larger the inequality, the smaller the resulting HDI (already depicted as GDI).

Scholars have criticized the estimation method of the GDI on the grounds it does not sufficiently account for gender inequality. They claim it reduces the visibility of discrimination, since it includes both absolute achievement and relative inequalities. Some authors want to reintroduce the first method the UNDP Reports used to measure gender inequality, which directly compares the different achievement degrees in human development of men and women. For their 
part, A. Geske Dijkstra and Lucia C. Hanmer (2000) suggested another alternative to the GDI: the Relative Status of Women, or RSW.

Gender analysts, in particular, have criticized the predominant use of the income component to measure gender inequality and the problems in international comparisons (Kalpana Bardhan and Stephan Klasen 1999; Paloma de Villota 1999). They claim that the "penalty" of gender income disparities has a "disproportionate" weight in the total penalty of the HDI after considering gender differences. This disproportion could be especially important in some (if not most) underdeveloped areas, where health or schooling inequalities are more serious than wage inequalities. The discussion on human development in developed countries has received less attention, and the UNDP only deals with areas of basic exclusion and poverty. The human suffering profiled in the reports is based on mortality causes in high-income countries. These include sedentary lifestyles and unbalanced diets, accidents, educational exclusion, unremunerated work or decreased social benefits, and other features related to the "weakening of the social fabric," such as alcohol abuse and drug-related crimes, divorces, single-parent families, suicides, young prison populations, etc., some of which imply controversial value judgments. Hence, the central themes in the Human Development Reports are discrimination, poverty, and exclusion. This is why, in terms of human development, penalties must arise from discrimination, since poverty and exclusion must be analyzed separately due to their specific nature. ${ }^{4}$

To reach a minimal scientific and academic consensus, it is useful to pay attention to gender and regional inequality when evaluating the "high" state of human development. We cannot assume that a society is highly developed when averages and means hide important variations or exclude an important population group. Measuring such inequalities is vital in order to give methodological and conceptual credibility to a human development paradigm, especially 
if this paradigm is meant to be universal, and not just an alternative to the economic growth model for the underdeveloped world.

\section{A Case Study: the Spanish State and its Autonomous Communities}

The Spanish case shows the need to take into account regional inequalities and gender discrimination when measuring human development. Spain is divided into seventeen political and administrative units called Autonomous Communities (hereinafter ACs). These ACs must be understood as something more than geographic regions, since they have varying degrees of selfgovernment and have received different powers regarding social policies. Likewise, some possess distinct national identities.

Underscoring the differences in these regions is the heterogeneous development of capitalism in Spain, the convulsive way it has been structured as a purely capitalist economy, and the obstacles certain regions still face as a result of the persistence of pre-capitalist and neocapitalist models. Not only have these factors had a general impact on the industrialization and modernization of the country, but they have also affected the integration and institutionalization of social status and gender roles. The regions traditionally called the "different Spains" (North/South, interior/coastal, humid/dry, modern/traditional, rich/poor, etc.) in fact prove the different degrees and stages of capitalist development in Spain: a) capitalist accumulation in the industrial and financial sectors in Catalonia and in the northern and central cities; b) agrarian capitalism accompanied by unproductive rentierism in the rest of Spain (the two Castillas, Galicia, and the South); c) "definitive capitalization," following an autarchic period and the mass expulsion of labor force from rural areas (emigration from Galicia and from the southern regions); and d) industrialization based on import substitution in the political and social framework of Franco's dictatorship. Although Spain's integration into the European Union and 
the nature of global capitalism have imposed a certain degree of homogenization, this "heritage" of regional inequalities can still be observed within the different Autonomous Communities.

As Table 1 shows, agriculture continues to play a very important role in the South (Andalusia, Extremadura, Murcia, and Castilla-La Mancha) and in Galicia, which have a combined output of more than half of the agricultural production in Spain and also have the highest agricultural employment rates $(12.9,16,13.2,12.8$, and 19.8 percent, respectively). Furthermore, these regions have the lowest per-capita gross domestic product (less than 10,217.21 euros), although redistribution of the gross household disposable income places some of them closer to or in a higher position than other communities in the medium-low boundary of 9,015.18 euros (Asturias, Castilla y Leon, the Canary Islands, the Valencian Community, and Cantabria). More than one-third of Spain's population lives in these lower-income regions, while another third resides in the urban centers of Madrid, Catalonia, and the Basque Country. Even when the cyclical nature of employment is taken into account, the southern ACs of Andalusia and Extremadura register exorbitant unemployment rates (close to 30 percent), much higher than all the others.

In addition to such regional disparities, Spain possesses, overall, one of the lowest levels of female participation in the labor market within the European Union. At the same time, the country has one of the highest levels of inactivity and unemployment. It is therefore a case in which the regional distribution of HDI and GDI should be especially taken into account, since these regionalized indexes show that a general HDI can hide important regional disparities as well as remarkable gender discrimination. Spain is thus an excellent example of the need to correct the level of human development in high-income countries, as measured by the HDI, by including inequality. If we bear in mind that Spanish women lack the same capabilities and opportunities Spanish men have, and that in some regions this deficiency is much greater than in 
others, it becomes clear that the true level of human development in Spain is not as high as the overall HDI suggests.

In the following sections, we underscore the importance of regional differences in Spain by examining the results of HDI and GDI estimations and analyzing components of these indices.

\section{HDI and GDI rankings for the Autonomous Communities}

HDI and GDI figures computed for the year 1997, following Atkinson's income reduction formula for income adjustment (a step we justify below), are shown in Table 2 and compared in Chart 1.

First, note that all of the Autonomous Communities have a GDI value that is lower than their HDI, illustrating that, when gender is taken into account, measures of human development decrease. This fact confirms the universality of gender discrimination in Spain. Andalusia, for instance, has the lowest Human Development Index in Spain -- 0.903. Yet this low value is higher than the highest GDI in all of the Autonomous Communities, the 0.881 rating of Madrid. This means that even the best level achieved in the gender-related index is worse than the lowest general index. Secondly, we should draw attention to the fact that GDI values are more regionally scattered than HDI values, implying that differences in Spaniards' capabilities and opportunities are greater when assessing gender inequality. We can thus infer that a gender approach is more appropriate than any other for measuring overall human development, because it allows us to stress the existing regional differences in a much clearer way. Finally, the different values of both indicators at a regional level changes the relative positions of the ACs, with their rankings rising or falling according to whether their HDIs or their GDIs are considered. These changes can be observed in the gradient and crossing-points - the steeper the gradient and the more intersections 
it shows, the larger the drop in the ranking position of the Autonomous Community in terms of gender-related human development (Chart 1).

Special mention must be made of extreme cases (Table 3): the ACs that either improve or lose relative positions in the rankings once gender discrimination has been taken into account. Gainers include the Canary Islands $(+11)$, the Balearic Islands (+8), Galicia (+5), and Catalonia (+4), while Aragon (-9), Cantabria (-5), La Rioja (-4), Castilla y Leon (-5), and Navarre (-5) show lowered human development outcomes. At the same time, the penalty that using the GDI imposes, both in absolute and in percentage terms, shows the different degrees of discrimination in human development in every AC (Table 3). These shifts in ranking positions and regional values, caused by the introduction of a gender approach, may be used to diagnose shortages in human development and to design policies aimed at improving its components.

\section{The Scope of Discrimination: Components of the GDI}

Using the "equally distributed equivalent achievement" (EDEA, once assessed by harmonic means ${ }^{5}$ ), the paradigm proposed by the United Nations Development Program can transform the general or average advance in each area of human capabilities and opportunities into another indicator that takes into account gender inequality. This transformation results in an HDI that is adjusted downwards for gender inequality -- that is, a GDI. But the effects of each component of human development -- life expectancy, educational attainment, and adjusted earned income -- on the measurement of inequality are very different. In fact, the monetary income component has such a prominence in the penalty that it distorts the reality of discrimination, both in the case of developing countries (because it overlooks health issues and lack of schooling for girls) and in the case of developed countries (because the penalty concerning the access to 
resources is directly related to the absolute income level) (Kalpana Bardhan and Stephan Klasen 1999).

In 1999, the United Nations changed the method for estimating the GDI, adjusting the differential treatment of income. Responding to the charge that the adjustment achieved by using Atkinson's method gave too much weight to the income component (UNDP 1999: 159), UNDP launched a logarithmic transformation of the income component. As a result, Spain, which had formerly ranked ninth in the world ranking of HDI (UNDP 1998) dropped to the twenty-first position (UNDP 1999). Because Spain's GDI also ranked twenty-first on the list, the drop in HDI ranking translated into an apparent improvement in the situation of women. This occurred because while figures in 1997 showed a large difference between the HDI and the GDI rankings - a disparity that indicated high discrimination rates -- differences between the rankings were erased in 1999.

In our case, the choice between one adjustment method or another (namely, Atkinson's formula or the logarithmic function) leads to differences both in the GDI figures of the ACs and in the positions they register in the ranking (Table 2). We chose Atkinson's method for income adjustment because, when applied to the Spanish case, it can provide a better explanation of gender inequality than the logarithmic method. The Atkinson's formula better illustrates gender inequality because it introduces a reduction in the income variable that causes a downward homogenization of the income level of the ACs. Therefore, it reduces differences among ACs in terms of total GDP. As a result, differences in the "equally distributed earned income index" $\left(E_{E D A}\right)$-- which is computed from the different wages and activity rates for men and women -account for the gender disparities among ACs in the income component and the GDI value itself. ${ }^{6}$ This means that women's income is limited with respect to the total income component. 
This effect on women's income becomes clearer when one observes that the correlation between per capita GDP and the GDI computed according to Atkinson's method is lower than the one that would result from the logarithmic adjustment. The correlation coefficient between the

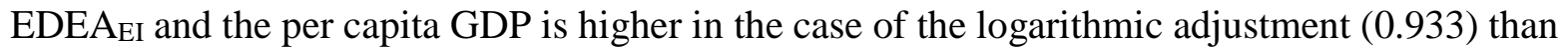
in the case of Atkinson's method of adjustment (0.508). But the level of correlation achieved by Atkinson's method is, on the contrary, higher in the correlations between the EDEAEI and the wage ratio (0.856) and between the EDEA $\mathrm{EI}_{\mathrm{E}}$ and women's labor-force participation (0.775); the logarithmic correlations are 0.414 and 0.435 , respectively. Thus, the EDEAEI (as well as the resulting GDI) computed according to Atkinson's method seems to integrate better into the GDI gender disparities between men and women regarding capabilities and opportunities in the economic field.

As for the remaining components of the GDI, the equally distributed life expectancy index and the equally distributed educational attainment index (EDEA $A_{L E}$ and EDEAED respectively), they barely register any change or dispersion. Differences in life expectancy indices and educational attainment indices are small within the different communities, indicating that discrimination against women in these spheres is practically nonexistent. In fact, the existing disparities in these indices among the different communities are a result of regional differences in the amount of absolute improvement rather than a result of gender differences. The apparent lack of discrimination in these two components of human development -- health and education -- also proves that in developed countries (and Spain is not an exception to this phenomenon), assuming there are no better variables to express achievement in those spheres, it is the income variable that accounts for gender discrimination in human development estimation.

The importance of the income variable becomes even clearer when we analyze the drop in the HDI associated with gender inequality and the effect of gender on the HDI's three 
components (Table 3). In view of the clear predominance of the income component in causing those drops, the explanation for the different degrees of gender inequality within Spain must be found in the income index. In order to locate this explanation, two indicators must be taken into account in the calculation of the EDEAEI: wage ratio (the ratio of female wage to male wage, $w r$ ) and women's labor force participation rate.

In regard to wage differences, Spain shows a high degree of regional dispersion in its wage ratios. Two extreme examples illustrate this dispersion: Madrid, the community with the lowest degree of wage discrimination, has a ratio of 79.2; and Aragon, the community with the highest degree of wage discrimination, has a ratio of 56.9. In fact, female wage equals at least three-quarters of male wages in only two ACs: Madrid and the Canary Islands. In the other Spanish communities, this ratio is even lower than the national average (74.3). ${ }^{7}$ Differences in women's labor force participation within the different communities are not as pronounced, although Spain's average is still far below that of Europe for such participation.

Thus, whereas regional disparities in "female share of earned income" are mainly due to wage differences, the low rate of women's participation in the labor force seems to be the main factor behind the unequal "female proportional income share." (We must, however, direct attention to the fact that the labor force participation of men was itself low, about 61 percent in 1997). Despite the fact that the employment rate of Spanish women has grown continuously since the 1960s, women are still highly confined to the domestic sphere. This restricted role, along with the visible lack of public policies aimed at promoting equality between men and women in the labor market, prevents women from having a stronger presence in the productive sphere (Cristina Carrasco and Arantxa Rodríguez 2000).

To show regional differences in human development -- be they general or stemming from gender inequality - we can draw two "autonomic maps" (Map 1 and Map 2). At first glance, with 
both indicators (HDI and GDI) taken into account, the maps depict the so-called two Spains, divided by an invisible line that separates the North and the South. The Canary Islands and Aragon are the only two exceptions, though these two communities drastically modify their positions once a gender approach has been introduced (the Canary Islands for the better, and Aragon for the worse). Looking at the Autonomic Map of Gender-Related Human Development (Map 2), we can divide the ACs into four groups, according to GDI values that range from a maximum value of 0.881 to a minimum value 0.816 :

1) Madrid, the Canary Islands, and the Basque Country are the communities with the smallest human development disparities between men and women;

2) Catalonia, Galicia, Navarre, and the Balearic Islands, which register slightly higher levels of inequality, can be categorized as the second group;

3) Castilla y Leon, Asturias, La Rioja, the Valencian Community, and Cantabria belong in the third group, with has wider inequalities; and

4) Murcia, Aragon, Andalusia, Extremadura, and Castilla-La Mancha occupy the last position. Here, the lowest general levels of development and the greatest level of discrimination create the worst-case scenario for women's human development.

By taking into account the rankings of the ACs and the numbers they received in the classification according to their GDI and its components, we can evaluate the "stability" of some communities, or the "discrimination asymmetry" of other communities. "Stable" communities are those that occupy similar positions in the ratings of all components -- at the top of the classification (Madrid or Catalonia), or at the bottom (Andalusia or Murcia). Examples of asymmetric communities -- those that occupy varying positions in the ratings of each GDI component -- are the Canary Islands, the Balearic Islands, and Aragon, which are asymmetric because of income disparities; Castilla-La Mancha, Castilla y Leon, and the Basque Country, 
which are asymmetric because of differences in men's and women's life expectancies; and the Canary Islands and the Basque Country, which are asymmetric because of gender disparities in educational attainments.

Therefore, for scholars who are performing the final assessment of gender differences in human development from an autonomic point of view, the different rankings of all components can provide a starting point for explaining the scope of gender discrimination. Without doubt, such assessments have important implications for social policies (as far as gender is concerned).

\section{Alternatives to the GDI}

Alternative measures of gender discrimination in human development focus mainly on variables and calculation methods. Although researchers should keep the basic indicators of the HDI (in order to retain useful measures of political operating capacity, comparability, etc.), they should also find "better" indicators to measure discrimination in life expectancy, adult literacy, and schooling ratios, as well as in income. Alternatively, they should combine existing indicators in a different way in order to calculate their synthetic (or integrated) value.

New approaches to research that follow these guidelines have emerged, such as an indicator called "disability-free life expectancy" instead of the former "life expectancy at birth." Another way of calculating gender discrimination would be to add indices such as scholastic failure, functional illiteracy, or career orientation to the measurement of educational attainment. With regard to income, it would be useful to account for discrimination in the productive sphere, which results not only from wage inequality (the failure to comply with the rule "equal pay for equal work"), but also from women's being mostly employed in lower paid occupations, which traditionally create most female jobs. 
Leaving aside the alternatives of income adjustment, some critics have objected to the fact that the GDI integrates discrimination, but does not measure it. Dijkstra and Hanmer (2000) have launched an alternative to the GDI, which they call the Relative Status of Women (RSW).

For economists, the great challenge is to integrate the reproductive economy into the human development field. Domestic work and care-giving responsibilities are generally invisible to researchers. As a result, their analyses overlook these fundamental parts of women's capabilities and opportunities (women's choices), which are in fact so essential that they both lay the foundations of the productive sphere itself and at the same time represent women's integration into the productive sphere. In this sense, the existing debate deals with the suitability and possibility of measuring reproductive work and the characteristics such measurements should have. $^{9}$

We will present two alternative calculations of the GDI based on each of these possibilities: a) a division of the economic field into sectors (industry and services) and b) a calculation of the Relative Status of Women for Spanish ACs. After studying the results and comparing them with the previously calculated GDI values, we draw some final conclusions and recommendations.

\section{Sectoral Reconstruction of Income Share}

In Spain, women's opportunities in the labor market exist mainly in the tertiary sector (two-thirds of all female workers are employed in this sector). Within this sector, more than onethird of women are employed in the "retail trade and hotel and catering trade," another third are civil servants, and one-sixth are employed in "other services" (especially "domestic service"). Almost two-thirds of the industrial female work force is employed in manufacturing and in the textile and clothing industries. Importantly, women's earnings are much lower than men's -- from 
25 to 30 percent lower -- in precisely these sectors: the textile and clothing industries, retail trade, and the hotel and catering trade. Moreover, the total average wage in these industries is only about 80 percent of the average industrial wage. Thus, the problem is not only gender discrimination but also sectoral discrimination.

Given these figures, we can calculate a GDI2, by reconstructing the equally distributed income coefficient of earnings of those two sectors (industry and services) out of national average data (unfortunately, no disaggregated data exists regarding ACs). The procedure is as follows: we estimate the coefficient between women's earnings and global earnings for each sector; we then multiply these results by the female working population percentage (for each AC). Then, we find the arithmetic average of these results, which gives rise to a new "female share of earned income." Divided by the percentage of women in the total population, this share equals a new "female proportional income share." We follow the same procedure to obtain male income share, and the harmonic mean of both resulting values accounts for the new equally distributed income coefficient. By following the same steps used to construct the GDI, we can then obtain the GDI2 (Table 4).

When we compare the new GDI2 with the GDI, we see that all ACs register a lower GDI2 than GDI; in all cases, therefore, the reconstruction of the income component translates into a better "visibility" of discrimination. Most likely, if we could use disaggregated data from the ACs, the results would even be more staggering. Despite the temporary and seasonal behavior of unemployment rates and the difficulties of using them to construct structural indices like the GDI, their inclusion into this reconstruction (by using the percentage of women actually working, rather than the female working population rate), would highlight disparities even more. In conclusion, since the income factor is the most important means, at least de facto, for accounting for gender differences in human development, the more we refine the measurement of 
discrimination against women in this area, the greater the decrease in the existing human development indices These lowered indices would allow us to better evaluate the difficulties that women really face when trying to improve their capabilities and opportunities in the labor market, which is clearly biased against them both sectorally and remuneratively.

Additionally, it is important to note that the GDI2 "reorganizes" the ACs, so that some change their positions in the rankings considerably: either shifting downward, like Galicia (which moves from the fifth position to the fifteenth) and the Canary Islands (from the third position to the eighth), or moving upward, as in the case of Navarre (from the sixth position to the second), La Rioja (from the tenth to the fifth), or Aragon (from the fourteenth to the seventh). These results seem more consistent if we bear in mind that these latter communities showed "exceptional" performances of the GDI in relation to the HDI. Yet, the South (Andalusia, Extremadura, Castilla-La Mancha, Murcia) continues to register lower levels than the North, which means that southern communities, along with Galicia, again hold the lowest positions. These communities also have, in relative terms, the sharpest drop in their GDI rankings (together with Asturias, the Canary Islands, and Galicia).

\section{Measuring, rather than integrating, inequality: the Relative Status of Women (RSW)}

Given that the aim of the GDI constructed by UNDP is to assess the level of achievement in the same areas as the HDI, while taking into account the disparity in achievement between men and women, the GDI is composed of absolute average advances and gender-related inequalities. The GDI therefore is just an HDI qualified by gender discrimination. This is why the GDI has been criticized as a gender inequality indicator. Some researchers have suggested constructing an index capable of abstracting absolute levels of welfare, so as to measure the absolute differences between men and women. Such is the proposal of Dijkstra and Hanmer (2000), who reintroduce 
UNDP's first measurements of inequality by using the HDI "adjusted in accordance to gender disparities." They have constructed the Relative Status of Women index (RSW), which is based on the arithmetic mean of female and male ratios of each of the components of human development.

For Spain, we have calculated the RSW in two different ways, according to the treatment given to the income index: a) we measured gender discrimination in the access to income by means of women's proportional share of income, following the Atkinson's method (RSW) (in this case, we compared women's wage with the average wage); and b) we measured women's share of resources according to the per-capita income ratio of women related to that of men for each AC, following the new logarithmic method of the UNDP (RSW2) (in this case, we have compared women's wage not to the average wage but to that of men) (Table 4). Although these new indices show different values depending on which measurement method has been used, in both cases the rankings of the different ACs remain unchanged. But if we compare the relative positions of the ACs based on the RSW with their positions based on the GDI, some variations can be observed, such as the improvement of the Balearic Islands' ranking and the lower position of Navarre's (these changes are similar to those registered when transforming the HDI into the GDI). On the other hand, differences among absolute values of RSW and RSW2 show the relevance of the method used to calculate the income disparities: the inequality expressed by the RSW2 (logarithms) is greater than the inequality expressed by either of the other two indicators, which had used the Atkinson's method (GDI and RSW).

The similarity of the RSW and the GDI values comes from the fact that penalties on the different components of the RSW are "counterbalanced": equality ratios of life expectancy and educational attainment (which are extremely similar) counteract the lower ratio of income 
equality. But in the case of the RSW2, the income inequality, which is given much more weight, "unbalances" this relative equality.

Thus, the most important advantage of this new index is that, because it focuses on absolute inequality rather than on relative inequality, it makes inequality between men and women evident in the area in which it is mainly concentrated--namely the access to monetary resources, where ratios are far from unity (or equality). As a result, the income ratio is the key to measuring gender discrimination among ACs: communities win (or lose) positions in the regional rankings created by the RSW relative to those constructed by the GDI depending on whether women's share of income is higher (or lower) than men's.

Even considering that the income sphere is the weightiest component of these alternative indicators, another of their advantages is that, since they do not consider the general level of achievements of a society, but direct attention only to gender indicators, they achieve an inequality index barely correlated to the absolute income level. The correlation coefficients of the RSW and the RSW2 with the per-capita GDP, which are 0.554 and 0.536 respectively, are smaller than the coefficient of the GDI adjusted by logarithms (0.993) and similar to that of the GDI adjusted following Atkinson's method (0.509). We can conclude that the RSW is a better index for measuring discrimination against women, regardless of the per-capita income level of a given society.

\section{Conclusions}

What does a high level of human development for women mean? The straight answer, according to the strict terms of the UNDP definition, would be enlarging women's capabilities and opportunities. However, because barriers of exclusion and discrimination fence out women's empowerment and opportunities, we recommend exploring two new ways to apply a gender 
approach to the human development paradigm: a) measuring women's human development, which will be lower than men's, and therefore lower than overall human development; and b) penalizing, or lowering, the overall achievement in human development by the amount of this discrimination. Each of these approaches use women's invisibility and society's disdain toward the reproductive sphere, as well as female inequality in the productive one, to demonstrate the origins of discrimination against women.

Which sphere, productive or reproductive, is the most important for human development? We should not consider this a rhetorical question if the answer will guide social policies and North-South cooperation strategies. Obviously, in subsistence economies or in the poorest sectors of low-income countries, productive and reproductive spheres are deeply related, and the prominence of the reproductive sphere is self-evident as a result of the weakness of the overall productive sphere. But in high-income countries the situation is very different, since the reproductive sphere operates differently than in poor countries. Although the reproductive domain retains, to a certain extent, a genuine invisibility as a result of the institutional deferment, the market provides alternatives to the domestic services and care-giving responsibilities that characterize it. Given the basic nature of the noneconomic components of human development (life expectancy and educational attainment), it is the discrimination within the productive sphere that has to be studied from the gender point of view. Moreover, taking on paid work offers women alternatives to laboring in the reproductive sphere: access to the household goods and care services offered by "the market" depends to a great extent on the income level of individuals.

The analysis of human development in high-income countries suffers from some limitations. Although the HDI must be adjusted in accordance with gender discrimination and exclusion, once this adjustment is made, the income component is the decisive factor. Lack of employment or low remuneration is what characterizes women's inequality within these 
countries. The only way to overcome this limitation is to use variables relating to health and education that are more specific than those of life expectancy and educational attainment. This requirement suggests that researchers should construct a specific HDI for high-income countries, composed of variables different from those used to assess human development in low-income countries. Another possibility for creating an HDI for high-income countries would be to use alternative indicators of inequality, taking into consideration that the general level of achievement also determines the degree of inequality: women are likely to be less discriminated against, both productively and reproductively, in a richer country than in a poorer one.

The Spanish case provides a good illustration of the above assertions. If we estimate the HDI and the GDI for the different ACs, we notice that absolute regional differences (which can be observed in the division between North and South, in terms of HDI) are combined with gender differences, which are mainly to be found in the income field. Wage differences between men and women, combined with a low female share of the labor force within the different ACs, are key factors that exacerbate the existing division between North and South.

But there are some exceptions to these general rules, as we encounter communities that significantly modify their positions in the ranking when we apply the GDI instead of the HDI. These exceptions highlight the importance of a gender approach. And, although it is possible to reveal higher levels of inequality (for instance, with a field analysis of women's employment and remuneration), the researcher always comes back to the extreme importance of the productive sphere. Leaving this prominence aside, in terms of its effect on overall human development, it is still vital to analyze its components in order to diagnose the most remarkable differences between men and women's capabilities and opportunities, above all in noneconomic areas.

Of course, no analysis of the productive sphere solves the problem of defining women's capabilities and opportunities in the reproductive sphere, either directly or indirectly, since the 
factors determining women's relationship to this sphere may not be under women's control. Actually, such factors seldom are -- hence the relevance of "empowerment." This is another reason for an alternative GDI, which would account for discrimination against women in highincome countries, not only in the productive sphere, but also in the reproductive one, by means of relatively simple indicators such as time use or the intensity of domestic work (starting from satellite accounts), among others. Discrimination must be integrated, not measured, a concept that includes accepting, for example, that active and skilled men in the household and care-giving fields are an improvement in terms of human development. The objective must be to increase the level of general human development, both for men and for women, instead of developing one at the other's expense. In terms of human development, the sharing of housework in the reproductive sphere is not a zero-sum game but a positive sum game (since it fosters human development for both men and women).

To sum up, we favor a double effort: the integration of a human development paradigm into gender analysis and the integration of a gender-aware approach into human development analysis. This effort would be especially useful in high-income countries. The human development paradigm, because of its multidimensional nature and its assessment of the general level of attainments, can broaden the perspective of the gender approach while strengthening its operating capacity; meanwhile, the gender approach, which unveils discrimination and inequality, can help to better evaluate the general level of achievement and to analyze it from a sociopolitical point of view.

Along the path toward this two-faceted process, case studies, either at a regional or national level, could be the ideal tools for spreading a new, more realistic, and socially useful description of human development for developed countries. Such descriptions could serve as guidelines for creating social, legal, and institutional policies aimed at eradicating discrimination 
and segregation against women, without fostering the tired excuse that improvements would be made "at the expense" of men.

Javier Martinez Peinado, Department of Economics, University of Barcelona Av. Diagonal 690, 08034 Barcelona, Catalonia-Spain e-mail: jmartine@eco.ub.es

Gemma Cairó Céspedes, Department of Economics, University of Barcelona Av. Diagonal 690, 08034 Barcelona, Catalonia-Spain e-mail: gcairo@eco.ub.es

Javier Martínez Peinado earned his PhD in Economics from the University of Barcelona, where he is now Lecturer in the Faculty of Economics on the topics of world economy and development economics. His most important publications include Estructura Económica y sistema capitalista mundial (1987), Desarrollo económico y superpoblación (1996), Economía mundial (1995 and 2000), and El capitalismo global (1999). He has also published a number of articles in specialized economic reviews in Spain and Latin America. He is coordinator of GREM (World Economy Research Group-University of Barcelona) and a member of REDEM (World Economy Studies Network). 
Gemma Cairó Céspedes earned her PhD in Economics from the University of Barcelona, where she is now Lecturer in the Faculty of Economics. She has coauthored several publications, including Crisis y ajuste en la economía mundial (1997) and Economía Mundial (1995 and 2000), and has published in specialized regional reviews such as Asian Survey and international trade reviews such as Boletín de Información Comercial Española (Ministry of Economy, Spain). She is a member of GREM (World Economy Research Group-University of Barcelona).

Address for Proofs:

Gemma Cairó Céspedes

Faculty of Economics

University of Barcelona (UB)

Av. Diagonal 690

08034 Barcelona

Catalonia-Spain

tel: 34934021922

fax: 34934024573

\section{REFERENCES}

Bakker, Isabella. 1999. "Dotar de Género a la Reforma de la Política Macroeconómica en la Era de la Reestructuración y el Ajuste Global” in Cristina Carrasco (ed.), Mujeres y Economía. Barcelona: Icaria. (originally published as The Strategic Silence: Gender and Economic Policy, London: Zed Books-North-South Institute, 1994)

Bardhan, Kalpana and Stephan Klasen. 1999. “UNDP’s Gender-Related Indices: A Critical Review." World Development 27(6): 985-1010.

Benería, Lourdes. 1992. “Accounting for Women’s Work: Progress of Two Decades.” World Development 20(11): 1547-60. 
Benería, Lourdes and Gita Sen. 1981. “Accumulation, Reproduction and Women's Role in Economic Development: Boserup Revisited.” In The Women, Gender and Development Reader, ed. Nalini Visvanathan, 42-50. London: Zed Books. (originally published in Signs. Journal of Women, Culture, and Society 7, no.2 (1981): 279-98.)

Boserup, Esther. 1993. La mujer y el desarrollo económico. Madrid: Minerva. (originally published as Woman's Role in Economic Development. London: Earthscan Publication, 1970.)

Carrasco, Cristina and Arantxa Rodríguez. 2000. "Women, Families and Work in Spain: Structural Change and New Demands." Feminist Economics 6(1): 45-57.

De Villota, Paloma. 1999. "Reflexiones Sobre el IDH Relacionado con el IDM-IDG del PNUD. La desigualdad de Género en España” in de Villota (ed.) Globalización y Género. Madrid: Síntesis.

Dijkstra, A. Geske and Lucia C. Hanmer. 2000. "Measuring Socio-economic Gender Inequality: Toward an Alternative to the UNDP Gender-Related Development Index." Feminist Economics 6(2): 41-75.

Elson, Diane and Nilufer Cagatay. 2000. "The Social Content of Macroeconomic Policies.” World Development 28(7): 1347-64.

Elson, Diane. 1995. "Gender Awareness in Modeling Structural Adjustment.” World Development 23(11): 1851-68. 
Floro, Maria S. 1995. "Economic Restructuring, Gender and the Allocation of Time." World Development 23 (11): 1913-29.

Ministerio de Trabajo y Seguridad Social. 1998. Perspectivas del Empleo 1998.

Pearson, Ruth. 1999. "El Género Cuenta en el Desarrollo" in Cristina Carrasco (ed.) Mujeres y Economía. Barcelona: Icaria. (originally in Poverty and Development in the 1990s, Tim Allen and Alan Thomas (eds.), 383-402. Oxford: Oxford University Press, 1992.)

PNUD, Informe Sobre Desarrollo Humano, Distintos Años, Madrid: Mundiprensa.

Tinker, Irene. 1990. Persistent Inequalities: Women and World Development. New York: Oxford University Press.

United Nations Development Programme. 1990. Human Development Report 1990: Concept and Measurement of Human Development. Oxford, UK: Oxford University Press.

United Nations Development Programme. 1995. Human Development Report 1995: Gender and Human Development. Oxford, UK: Oxford University Press.

United Nations Development Programme. 1998. Human Development Report 1998:

Consumption for Human Development. Oxford, UK: Oxford University Press. 
United Nations Development Programme. 1999. Human Development Report 1999:

Globalization with a Human Face. Oxford, UK: Oxford University Press.

Young, Kate. 1997a. "Gender and Development" in The Women, Gender and Development Reader, ed. Nalini Visvanathan. London: Zed Books.

Young, Kate. 1997b. "Planning for a Gender Perspective: Making a World of Difference" in The Women, Gender and Development Reader, ed. Nalini Visvanathan, 366-74. London: Zed Books.

Zabala, Idoye. 1999. “Un Viaje a Través del Tiempo: 30 Años de Pensamiento Económico Feminista en Torno al Desarrollo" in Cristina Carrasco (ed.). Mujeres y Economía. Barcelona: Icaria. 
Table 1. Regional Disparities in Spain. 1997

\begin{tabular}{|c|c|c|c|c|c|c|c|}
\hline $\begin{array}{l}\text { Autonomous } \\
\text { Communities }\end{array}$ & HDI & $\begin{array}{c}\text { Total } \\
\text { Population } \\
(\%)\end{array}$ & $\begin{array}{c}\text { Per capita } \\
\text { income } \\
\text { (pesetas) }\end{array}$ & $\begin{array}{c}\text { Per capita } \\
\text { GHDI } \\
\text { (pesetas) }\end{array}$ & $\begin{array}{l}\text { Unemploy } \\
\text { ment rate }\end{array}$ & $\begin{array}{l}\text { Agricultural } \\
\text { workers } \\
\text { (\% total } \\
\text { agricultural } \\
\text { workers) }\end{array}$ & $\begin{array}{l}\text { Agricultural } \\
\text { workers (\% } \\
\text { regional } \\
\text { workers) }\end{array}$ \\
\hline Andalusia & 0.903 & 18.26 & $1,434.998$ & $1,266.098$ & 29.45 & 23.8 & 12.9 \\
\hline Aragon & 0.927 & 2.99 & $2,140.584$ & $1,762.098$ & 11.37 & 4.0 & 9.9 \\
\hline Asturias & 0.920 & 2.74 & $1,743.329$ & $1,472.545$ & 19.07 & 3.2 & 10.6 \\
\hline Balearic Islands & 0.907 & 1.96 & $2,966.384$ & $2,165.019$ & 11.12 & 0.7 & 2.5 \\
\hline Canary Islands & 0.909 & 4.08 & $2,036.180$ & $1,530.809$ & 18.78 & 3.5 & 6.8 \\
\hline Cantabria & 0.923 & 1.33 & $1,821.116$ & $1,533.637$ & 18.22 & 1.6 & 9.9 \\
\hline Castilla y León & 0.929 & 6.30 & $1,798.631$ & $1,563.993$ & 18.04 & 9.4 & 12.3 \\
\hline Castilla-La Mancha & 0.909 & 4.33 & $1,585.019$ & $1,406.251$ & 17.06 & 6.6 & 12.8 \\
\hline Catalonia & 0.922 & 15.44 & $2,451.747$ & $1,732.172$ & 14.38 & 7.5 & 3.5 \\
\hline Valencian Com. & 0.910 & 10.13 & $1,973.000$ & $1,565.377$ & 16.79 & 7.4 & 5.7 \\
\hline Extremadura & 0.907 & 2.70 & $1,444.223$ & $1,352.591$ & 28.98 & 4.4 & 16.0 \\
\hline Galicia & 0.916 & 6.90 & $1,669.934$ & $1,499.010$ & 17.34 & 17.1 & 19.8 \\
\hline Madrid & 0.931 & 12.76 & $2,552.791$ & $1,748.132$ & 16.92 & 1.8 & 1.0 \\
\hline Murcia & 0.912 & 2.79 & $1,585.027$ & $1,369.979$ & 17.35 & 4.6 & 13.2 \\
\hline Navarre & 0.933 & 1.33 & $2,326.350$ & $1,652.908$ & 10.03 & 1.8 & 9.6 \\
\hline Basque Country & 0.928 & 5.29 & $2,258.169$ & $1,674.056$ & 17.23 & 1.7 & 2.4 \\
\hline La Rioja & 0.924 & 0.67 & $2,227.395$ & $1,810.014$ & 11.18 & 0.8 & 10.1 \\
\hline SPAIN & 0.918 & 100 & $1,987.539$ & $1,555.446$ & 18.82 & 100 & 8.0 \\
\hline
\end{tabular}

Notes: Unemployment rate and agricultural workers figures correspond to 1998. GHDI (Gross Household Disposable Income, PPP)

Source: Own calculations based on INEBASE; Fundación BBV (1999): Renta Nacional de España y su distribución funcional; Instituto Nacional de Estadística (1999): España en Cifras 1999; Papeles de Economía Española, nº 80, 1999. 


\section{Chart 1. HDI-GDI Compared}

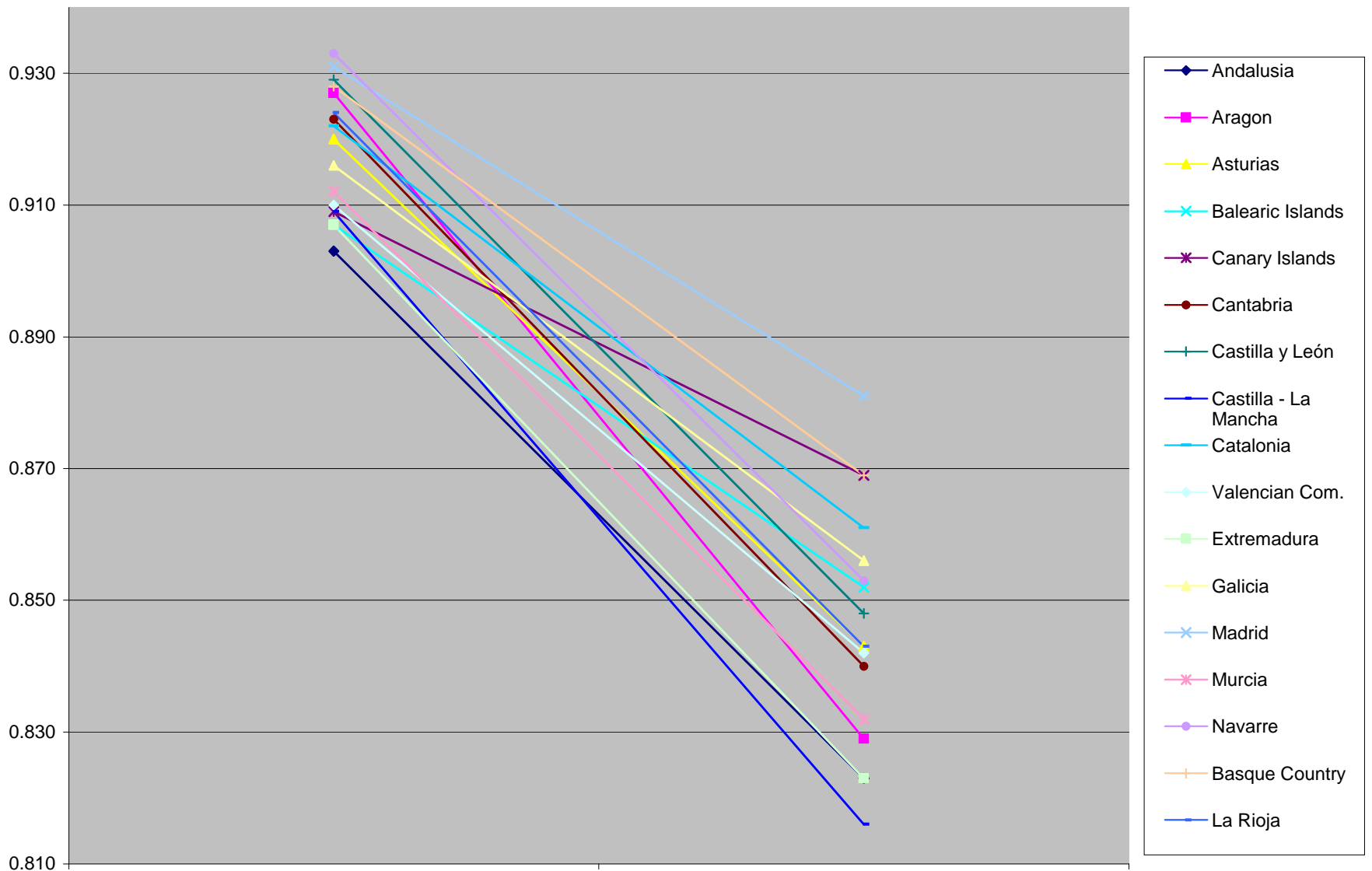

HDI

GDI 
Table 2. HDI-GDI Differences by Penalty Component

\begin{tabular}{|l|c|c|c|c|c|c|c|}
\hline \multicolumn{1}{|c|}{$\begin{array}{c}\text { Autonomous } \\
\text { Communities }\end{array}$} & EDEA $_{\text {LE }}$ & EDEA $_{\text {ED }}$ & $\begin{array}{c}\text { EDEA } \\
(\mathbf{L o g})\end{array}$ & $\begin{array}{c}\text { EDEA } \\
(\text { Atk })\end{array}$ & $\begin{array}{c}\text { GDI } \\
(\text { Log })\end{array}$ & $\begin{array}{c}\text { GDI } \\
(\text { Atk })\end{array}$ & HDI \\
\hline Andalusia & 0.865 & 0.894 & 0.758 & 0.709 & 0.839 & 0.823 & 0.903 \\
\hline Aragon & 0.895 & 0.935 & 0.821 & 0.658 & 0.883 & 0.829 & 0.927 \\
\hline Asturias & 0.871 & 0.937 & 0.794 & 0.721 & 0.867 & 0.843 & 0.920 \\
\hline Balearic Islands & 0.869 & 0.899 & 0.886 & 0.789 & 0.885 & 0.852 & 0.907 \\
\hline Canary Islands & 0.872 & 0.904 & 0.824 & 0.829 & 0.867 & 0.869 & 0.909 \\
\hline Cantabria & 0.885 & 0.931 & 0.798 & 0.704 & 0.871 & 0.840 & 0.923 \\
\hline Castilla y León & 0.906 & 0.932 & 0.798 & 0.707 & 0.879 & 0.848 & 0.929 \\
\hline Castilla - La Mancha & 0.891 & 0.885 & 0.776 & 0.673 & 0.851 & 0.816 & 0.909 \\
\hline Catalonia & 0.887 & 0.927 & 0.850 & 0.769 & 0.888 & 0.861 & 0.922 \\
\hline Valencian Com. & 0.870 & 0.907 & 0.813 & 0.748 & 0.864 & 0.842 & 0.910 \\
\hline Extremadura & 0.882 & 0.888 & 0.761 & 0.698 & 0.843 & 0.823 & 0.907 \\
\hline Galicia & 0.879 & 0.918 & 0.785 & 0.770 & 0.861 & 0.856 & 0.916 \\
\hline Madrid & 0.898 & 0.944 & 0.862 & 0.801 & 0.901 & 0.881 & 0.931 \\
\hline Murcia & 0.874 & 0.910 & 0.774 & 0.712 & 0.853 & 0.832 & 0.912 \\
\hline Navarre & 0.900 & 0.948 & 0.842 & 0.712 & 0.896 & 0.853 & 0.933 \\
\hline Basque Country & 0.884 & 0.950 & 0.837 & 0.774 & 0.890 & 0.869 & 0.928 \\
\hline La Rioja & 0.890 & 0.931 & 0.834 & 0.706 & 0.885 & 0.843 & 0.924 \\
\hline SPAIN & 0.838 & 0.918 & 0.801 & 0.779 & 0.867 & 0.860 & 0.918 \\
\hline
\end{tabular}

Source: Instituto Nacional de Estadística

Notes: EDEA $\mathrm{LE}_{\mathrm{LE}}$ : Equally distributed life expectancy index

EDEA $_{E D}$ : Equally distributed education attainment index

EDEA $_{\mathrm{EI}}$ : Equally distributed earned income index. Log: Logarithmic method; Atk: Atkinson method. 
Table 3. GDI Components (penalty)

\begin{tabular}{|c|c|c|c|c|c|c|c|c|}
\hline \multirow{2}{*}{$\begin{array}{l}\text { Autonomous } \\
\text { Communities }\end{array}$} & \multirow{2}{*}{ HDI } & \multirow{2}{*}{ GDI } & \multirow{2}{*}{$\begin{array}{c}\text { Ranking } \\
\text { position } \\
\text { variation }(H D I \\
\text { - GDI) }\end{array}$} & \multirow{2}{*}{$\begin{array}{c}\text { Absolute } \\
\text { penalty }\end{array}$} & \multirow{2}{*}{$\begin{array}{l}\text { Relative } \\
\text { Penalty } \\
\quad(\%)\end{array}$} & \multicolumn{3}{|c|}{ Share of penalty } \\
\hline & & & & & & $\begin{array}{c}\text { Life } \\
\text { Expectancy }\end{array}$ & Education & $\begin{array}{l}\text { Earned } \\
\text { Income }\end{array}$ \\
\hline Andalusia & 0.903 & 0.823 & 2 & 0.080 & 8.9 & 0.4 & 0.0 & 99.5 \\
\hline Aragon & 0.927 & 0.829 & -9 & 0.098 & 10.5 & 0.3 & 0.0 & 99.8 \\
\hline Asturias & 0.920 & 0.843 & 0 & 0.077 & 8.4 & 1.1 & -0.1 & 99.1 \\
\hline Balearic Islands & 0.907 & 0.852 & 8 & 0.054 & 6.0 & 0.6 & -0.2 & 99.5 \\
\hline Canary Islands & 0.909 & 0.869 & 11 & 0.040 & 4.5 & 0.7 & -0.1 & 99.4 \\
\hline Cantabria & 0.923 & 0.840 & -5 & 0.083 & 9.0 & 0.7 & -0.1 & 99.4 \\
\hline Castilla y León & 0.929 & 0.848 & -5 & 0.081 & 8.7 & 0.3 & -0.8 & 100.4 \\
\hline Castilla - La Mancha & 0.909 & 0.816 & -3 & 0.093 & 10.2 & 0.1 & 0.0 & 99.9 \\
\hline Catalonia & 0.922 & 0.861 & 4 & 0.061 & 6.6 & 0.8 & -0.2 & 99.4 \\
\hline Valencian Com. & 0.910 & 0.842 & 1 & 0.068 & 7.5 & 0.5 & -0.2 & 99.7 \\
\hline Extremadura & 0.907 & 0.823 & 0 & 0.084 & 9.3 & 0.2 & 0.0 & 99.8 \\
\hline Galicia & 0.916 & 0.856 & 5 & 0.060 & 6.6 & 1.2 & -0.3 & 99.1 \\
\hline Madrid & 0.931 & 0.881 & 1 & 0.050 & 5.4 & 1.6 & -0.2 & 98.6 \\
\hline Murcia & 0.912 & 0.832 & -2 & 0.080 & 8.7 & 0.3 & -0.1 & 99.8 \\
\hline Navarre & 0.933 & 0.853 & -5 & 0.080 & 8.5 & 0.3 & -0.2 & 99.9 \\
\hline Basque Country & 0.928 & 0.869 & 1 & 0.059 & 6.4 & 1.0 & -0.3 & 99.3 \\
\hline La Rioja & 0.924 & 0.843 & -4 & 0.081 & 8.8 & 0.2 & -0.1 & 99.9 \\
\hline SPAIN & 0.918 & 0.860 & 0 & 0.058 & 6.3 & 1.2 & -0.2 & 99.1 \\
\hline
\end{tabular}


Map 1. HDI Autonomic Map

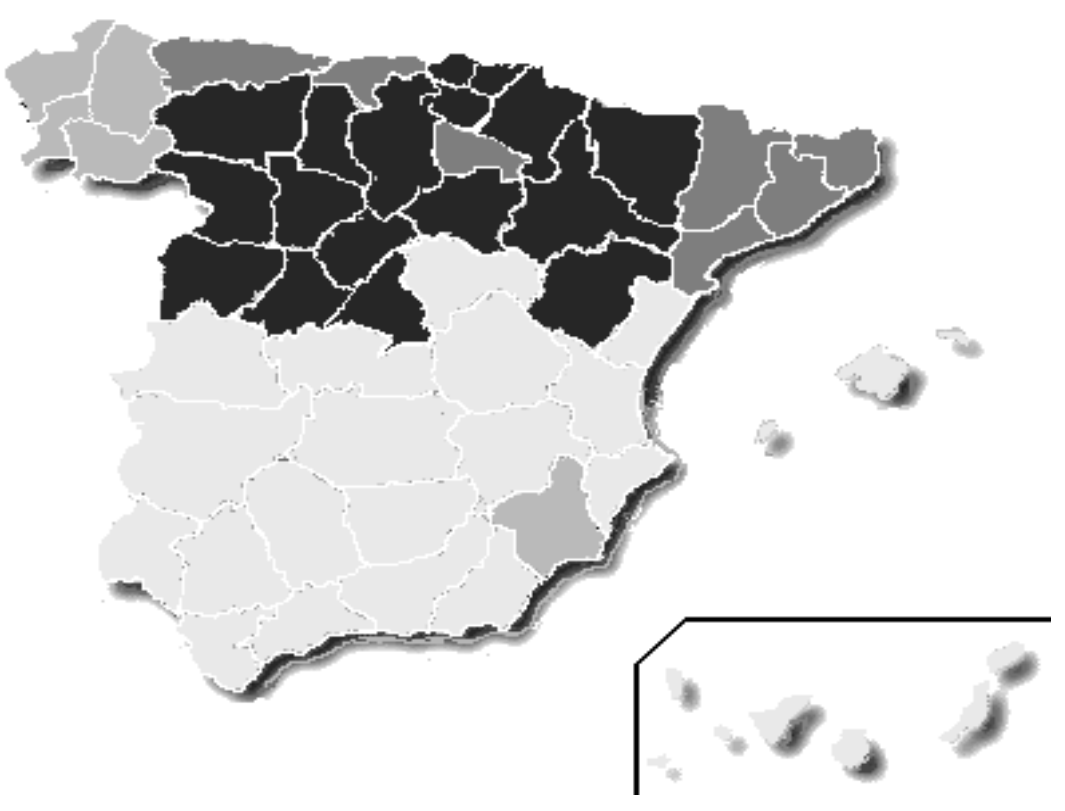

$$
\begin{aligned}
& \square \quad 0.933-0.925 \\
& \square \quad 0.924-0.919 \\
& \square \quad 0.918-0.912 \\
& \square \quad 0.911-0.903
\end{aligned}
$$


Map 2. GDI Autonomic Map

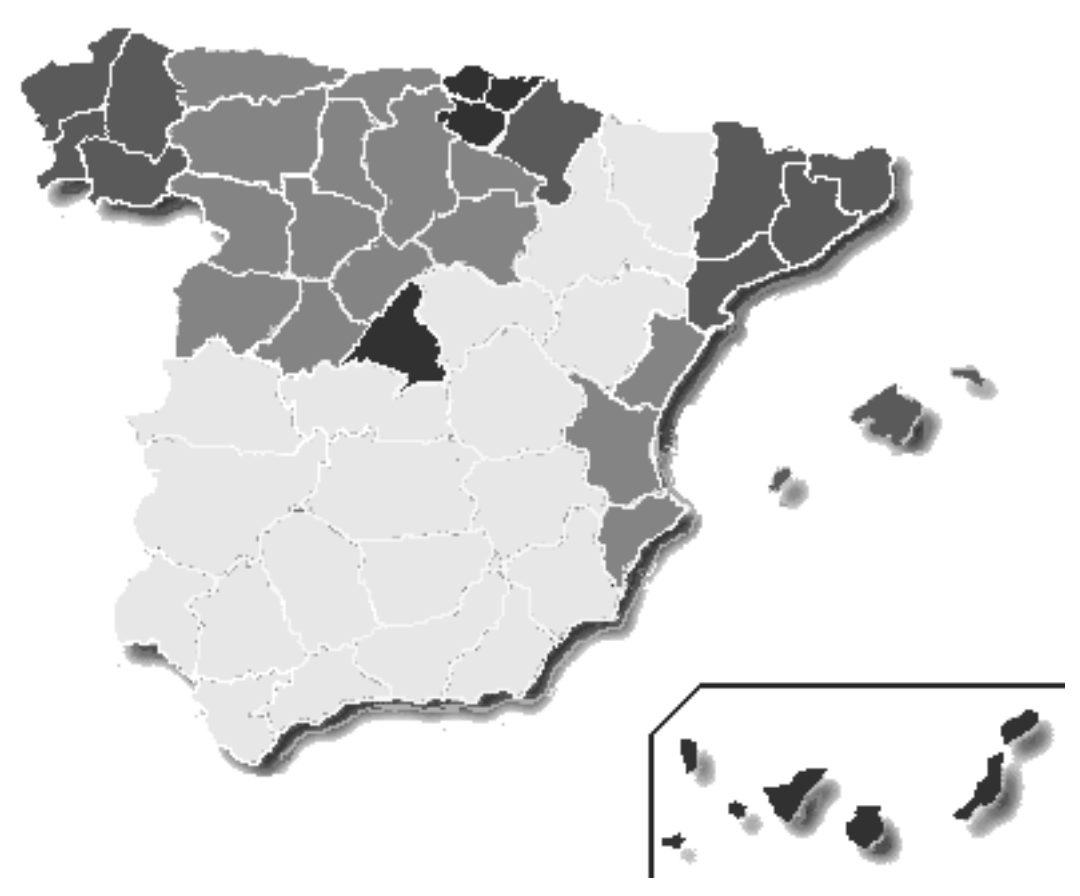

$0.881-0.864$

$\square \quad 0.863-0.849$

$\square \quad 0.848-0.833$

$\square \quad 0.832-0.816$ 
Table 4. GDI Alternatives: Relative Status of Women (RSW) and GDI2

\begin{tabular}{|l|c|c|c|c|c|c|c|c|}
\hline & $\begin{array}{l}\text { LEIf / } \\
\text { LEIm }\end{array}$ & $\begin{array}{c}\text { EDIf/ } \\
\text { EDIm }\end{array}$ & PISf & RSW & $\begin{array}{c}\text { p.c. income f } \\
\text { p.c. income m }\end{array}$ & RSW2 & GDI & GDI2 \\
\hline Andalusia & 1.043 & 0.967 & 0.52 & 0.843 & 0.377 & 0.796 & 0.823 & 0.758 \\
\hline Aragon & 1.027 & 0.996 & 0.464 & 0.829 & 0.320 & 0.781 & 0.829 & 0.818 \\
\hline Asturias & 1.062 & 1.005 & 0.544 & 0.870 & 0.402 & 0.823 & 0.843 & 0.793 \\
\hline Balearic Islands & 1.045 & 0.994 & 0.618 & 0.886 & 0.474 & 0.838 & 0.852 & 0.825 \\
\hline Canary Islands & 1.050 & 0.994 & 0.663 & 0.902 & 0.512 & 0.852 & 0.869 & 0.815 \\
\hline Cantabria & 1.056 & 1.002 & 0.522 & 0.860 & 0.386 & 0.814 & 0.84 & 0.802 \\
\hline Castilla y León & 1.034 & 1.045 & 0.516 & 0.865 & 0.372 & 0.817 & 0.848 & 0.803 \\
\hline $\begin{array}{l}\text { Castilla - La } \\
\text { Mancha }\end{array}$ & 1.012 & 0.969 & 0.475 & 0.819 & 0.326 & 0.769 & 0.816 & 0.781 \\
\hline Catalonia & 1.047 & 1.003 & 0.593 & 0.881 & 0.446 & 0.832 & 0.861 & 0.835 \\
\hline $\begin{array}{l}\text { Valencian } \\
\text { Com. }\end{array}$ & 1.034 & 0.996 & 0.565 & 0.865 & 0.419 & 0.816 & 0.842 & 0.810 \\
\hline Extremadura & 1.038 & 0.971 & 0.503 & 0.837 & 0.356 & 0.788 & 0.823 & 0.748 \\
\hline Galicia & 1.053 & 0.995 & 0.602 & 0.883 & 0.459 & 0.836 & 0.856 & 0.771 \\
\hline Madrid & 1.058 & 0.995 & 0.628 & 0.894 & 0.467 & 0.840 & 0.881 & 0.856 \\
\hline Murcia & 1.030 & 0.980 & 0.521 & 0.844 & 0.375 & 0.795 & 0.832 & 0.791 \\
\hline Navarre & 1.035 & 1.030 & 0.521 & 0.862 & 0.379 & 0.815 & 0.853 & 0.844 \\
\hline $\begin{array}{l}\text { Basque } \\
\text { Country }\end{array}$ & 1.066 & 1.025 & 0.602 & 0.898 & 0.462 & 0.851 & 0.869 & 0.839 \\
\hline La Rioja & 1.031 & 1.007 & 0.51 & 0.849 & 0.359 & 0.799 & 0.843 & 0.832 \\
\hline SPAIN & 1.044 & 0.995 & 0.603 & 0.881 & 0.452 & 0.831 & 0.86 & 0.815 \\
\hline Notes: & & & & & & & & \\
\hline
\end{tabular}

\section{Notes:}

$\mathrm{f}$ : female ; $\mathrm{m}$ : male

LEl: Life Expectancy Index

EDI: Education Attainment Index

PISf: Female Proportional Income Share

RSW: Relative Status of Women (based on PISf)

p.c. income: per capita income

RSW2: Relative Status of Women (based on per capita income (GDP)

GDI2: Sectoral Reconstruction of GDI

\footnotetext{
${ }^{1}$ This article contains some of the results of a larger project: "Human Development and Poverty: A Gender

Approach,” financed by the Women's Institute of the Ministry of Social Affairs (Instituto de la Mujer del

Ministerio de Asuntos Sociales) in Spain.
} 
${ }^{2}$ Not until the Cairo Conference on Population and Development, in 1994, did some researchers emphasize the relevance of women in analyzing population policy. Until then, the subjects (and objects) of demographic policies, family planning law, etc., were a mix of "family," "parents," and, to a lesser extent, of "women," as shown by the endorsement of the final papers at the population conferences held in Bucharest and Mexico in 1974 and 1984, respectively.

${ }^{3}$ To gain insight into this problem, it is essential to consider the link between the productive and reproductive spheres. If women take full responsibility for domestic work — their position in the labor market is weakened and they must depend on men's wages. This situation results in asymmetrical gender relationships. The traditional approach fails to provide an analysis of subordination, because it focuses on the production of goods without providing a global perspective on gender relationships in both the productive and the reproductive fields. ${ }^{4}$ According to the human development paradigm, the multidimensional deprivation of human development is a case of "human poverty." So, development and poverty would be the two ways (achievement and hardship) of regarding a single process. We have considered the feminization of human poverty in our other research, not included in this paper.

${ }^{5}$ Or, as the terminology in the Human Development Reports shows, the GESI formula (Gender Equity Sensitive Indexes). This formula refers to the design of each component index through a harmonic mean of the corresponding male and female indices, adjusted in accordance with the gender composition of the whole population.

${ }^{6}$ In the logarithmical method, in order to make the calculation of the "equally distributed earned income index" $\left(\mathrm{EDEA}_{\mathrm{EI}}\right.$ ), the total GDP (of both men and women) is applied to female participation in wages. As a result, gender differences in share of income among Autonomous Communities are partially concealed by the total income level of each community.

${ }^{7}$ We must throw into relief how, in this case, the national average hides differences among the Autonomous Communities of up to 23 percent. The data source, the INEBASE, gives no explanation of how the national average is estimated, which is quite surprising, since in 15 out of 17 Autonomous Communities this ratio is substantially below the national figures. One explanation could be that most of the working women are employed in communities where inequalities are less pronounced.

${ }^{8}$ We wish to thank our female colleagues at the Center for Women's Studies at the University of Alicante (Centro de Estudios de la Mujer de la Universidad de Alicante) for their suggestions and comments on these 
approaches during the presentation of this paper. Unfortunately, we do not have disaggregated data pertaining to ACs and gender.

${ }^{9} \mathrm{~A}$ recent landmark in this respect was reached at the symposium "Times, Jobs and Gender," organized by the Jobs, Institutions and Gender research group (Treballs, Institucions i Gènere) of the Universitat de Barcelona, in February 2001. 